\title{
Environmental impacts of large-scale grid-connected ground-mounted PV installations
}

\author{
Antoine Beylot ${ }^{1 *}$, Jérôme Payet ${ }^{1}$, Clément Puech ${ }^{2}$, Nadine Adra ${ }^{2}$, Philippe Jacquin ${ }^{3}$, \\ Isabelle Blanc ${ }^{4}$, Didier Beloin-Saint-Pierre ${ }^{4}$ \\ ${ }^{1}$ CYCLECO, Ambérieu-en-Bugey, France \\ ${ }^{2}$ Transénergie, Ecully, France \\ ${ }^{3}$ PHK consultants, Ecully, France \\ ${ }^{4}$ MINES ParisTech Sophia Antipolis, France \\ *Corresponding author.Tel: +33 437860712, E-mail: antoine.beylot@cycleco.eu
}

\begin{abstract}
This study characterizes the environmental performances of large-scale ground-mounted PV installations by considering a life-cycle approach. The methodology is based on the application of the existing international standards of Life Cycle Assessment (LCA). Four scenarios are compared, considering fixedmounting structures with (1) primary aluminum supports or (2) wood supports, and mobile structures with (3) single-axis trackers or (4) dual-axis trackers. Life cycle inventories are based on manufacturers' data combined with additional calculations and assumptions. Fixed-mounting installations with primary aluminum supports show the largest environmental impact potential with respect to human health, climate change and energy consumption. The climate change impact potential ranges between 37.5 and $53.5 \mathrm{gCO}_{2} \mathrm{eq} / \mathrm{kWh}$ depending on the scenario, assuming $1700 \mathrm{kWh} / \mathrm{m}^{2}$.yr of irradiation on an inclined plane $\left(30^{\circ}\right)$, and multi-crystalline silicon modules with $14 \%$ of energy production performance. Mobile PV installations with dual-axis trackers show the largest impact potential on ecosystem quality, with more than a factor 2 of difference with other considered installations. Supports mass and composition, power density (in $\mathrm{MW}_{\mathrm{p}}$ /acre of land) and energy production performances appear as key design parameters with respect to large-scale ground mounted PV installations environmental performances, in addition to modules manufacturing process energy inputs.
\end{abstract}

Keywords: Environmental impacts, LCA, PV installations

\section{Introduction}

PV systems deployment and solar energy use are developing rapidly in Europe. In particular, Austria, Switzerland, Germany, France, Italy and the Netherlands experienced a two to fourfold increase in their annual installed photovoltaic power in 2009 [1]. Large scale PV systems (> $500 \mathrm{kWp}$ ) represent a lower share of the photovoltaic power production compared to small scale systems $(<3 \mathrm{kWp})$. However, their market is showing a dramatic increase in number of installations. In France a 90\% increase was observed between the $2^{\text {nd }}$ and $1^{\text {st }}$ trimesters 2010 for installations of power superior to $500 \mathrm{kWp}$, compared to a $38 \%$ increase for small scale installations [2].

In this context of rapid development, the issue of PV systems environmental impacts characterization has been intensively addressed and discussed. While several initial publications underlined the higher external environmental costs of PV compared to those of nuclear energy and natural-gas-fuel power plants [3,4], new LCA databases have been built to comply with the improvements in PV systems [5,6]. They highlighted the photovoltaic potential for a low carbon energy supply and the environmental benefits of PV as opposed to fossil-fuel based energy [7, 8]. LCA data currently consider solar cells, panels and installation equipments production in the supply chain of different technologies. Up to now, most studies have focused on module technologies and small-scale installations. They exposed the key parameters for environmental performances of PV installations, when focusing on greenhouse gas emissions and primary energy use as environmental indicators: irradiation intensity received by PV installations, modules manufacturing electricity use and its corresponding fuel 
mix and PV technology [9, 12]. However, only few evaluations of large-scale PV installations can be found in the literature $[13,14]$.

This study aims at characterizing the environmental impacts of large-scale grid-connected ground-mounted PV installations (5MWp), considering one module technology (mc-Si) with different structures and types of supports (fixed-mounting or mobile). The results highlight key parameters related to large scale PV systems environmental performances on a life cycle perspective. Impacts on climate change and energy consumption are considered as indicators for the environmental assessment together with human health and ecosystem quality indicators. Recommendations are finally given to enable stakeholders in the field of large scale PV systems to minimize the environmental impacts of future installations.

\section{Methodology}

This Life Cycle Assessment (LCA) study was performed in compliance with the ISO standards 14040 and 14044 [15, 16] and followed the provisions of the ILCD handbook [17].

\subsection{Scope of the study}

The Functional Unit is defined as the kWh of electricity produced by a large-scale gridconnected ground-mounted PV installation (5MWp), considering $1700 \mathrm{kWh} / \mathrm{m}^{2}$.yr of irradiation on an inclined plane $\left(30^{\circ}\right)$ and 30 years of life expectancy.

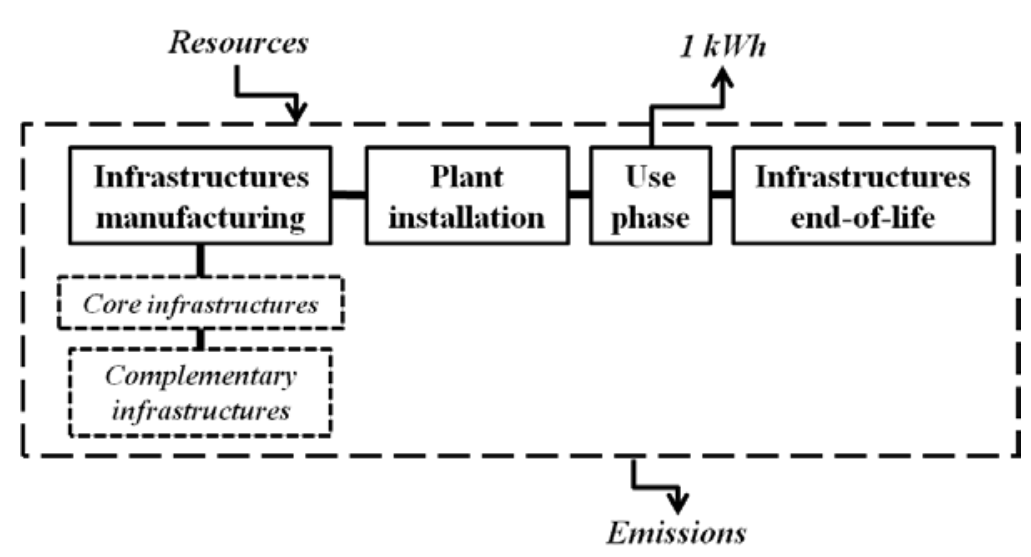

Fig. 1. Scheme of system boundaries

The system boundaries are described in Fig. 1. They include the manufacturing of core infrastructures (modules, mounting system, cabling, inverters, transformers), the manufacturing of I complementary infrastructures I (wire fences, control centers and road to access the plant), the plant installation (excavation and track construction), the use phase and the decommissioning (excavation, modules and structures end-of-life). Recycled waste material is assumed to substitute for primary produced material, without considering any correction factor.

Four grid-connected ground-mounted PV installations are compared in the study. Their differentiating key features are detailed in Tables 1 and 2. The multi-crystalline silicon (mcSi) PV technology is chosen for every scenario. Consequently, only the type of structure and its related system energy production differentiate the scenarios.

Life cycle impact assessment is performed with the use of the IMPACT 2002+ method (v2.04) [18]. The results focus on four damage impact categories: climate change, resources, human health and ecosystem quality. The temporary carbon storage in bio-based goods (wood supports in one scenario) is taken into account in compliance with ILCD provisions, i.e. by considering “-0.01 kg CO $\mathrm{CO}_{2}$-equivalents” per $1 \mathrm{~kg}$ carbon dioxide and 1 year of storage/delayed emissions. 
Table 1. Scenarios key features

\begin{tabular}{lcccc}
\hline $\begin{array}{l}\text { Scenarios } \\
\text { Module } \\
\text { Technology }\end{array}$ & 1 & 2 & 3 & 4 \\
$\begin{array}{l}\text { Structure key } \\
\text { features }\end{array}$ & mc-Si & mc-Si & mc-Si & mc-Si \\
& $\begin{array}{c}\text { Primary aluminum } \\
\text { supports }\end{array}$ & $\begin{array}{c}\text { Food-based } \\
\text { supports }\end{array}$ & $\begin{array}{c}\text { Single-axis } \\
\text { trackers }\end{array}$ & $\begin{array}{c}\text { Dual-axis } \\
\text { trackers }\end{array}$ \\
\hline
\end{tabular}

\subsection{Inventory}

The inventory distinguishes between:

- foreground processes, corresponding to PV systems parameters, land occupation and electricity use and generation, for which specific data have been used.

- upstream and downstream processes, corresponding to materials extraction and transformation, PV modules fabrication, materials and products transport, electricity production mix, infrastructures end-of-life, for which semi-specific or generic data have been used. Ecoinvent v2.0 [19] was used as the reference database for semi-specific data.

\subsubsection{PV installations electricity production}

Energy efficiency of the PV modules is set at $14 \%$, with an average performance ratio of 0.855 for the system. The increase in production thanks to mobility is respectively set to $5 \%$ for Scenario 3 considering single-axis trackers and to 32.5\% for Scenario 4 considering dualaxis trackers, based on average manufacturers' data. The corresponding electricity generated over the 30 years installation life-time is given in Table 2 for the 4 scenarios.

Table 2. Energy production in scenarios

\begin{tabular}{|c|c|c|c|c|}
\hline Scenarios & 1 & 2 & 3 & 4 \\
\hline $\begin{array}{l}\text { Increase in production } \\
\text { due to mobility }\end{array}$ & - & - & $\begin{array}{c}\text { 5\% (Average data from } \\
\text { a Spanish supports } \\
\text { manufacturer) }\end{array}$ & $\begin{array}{c}\text { 32.5\% (Average data } \\
\text { from an Italian supports } \\
\text { manufacturer) }\end{array}$ \\
\hline $\begin{array}{l}\text { Electricity production } \\
\text { over } 30 \text { years (in } G W h \text { ) }\end{array}$ & 218.0 & 218.0 & 228.9 & 288.9 \\
\hline
\end{tabular}

\subsubsection{Infrastructures}

Data on infrastructures of large-scale PV installations have been either directly collected or calculated from manufacturers data, as detailed in Table 3 . Ten $500 \mathrm{~kW}$ inverters are necessary for each PV installation, assuming 10 years of life expectancy (i.e. 30 inverters over each installation life-time), and five $1 \mathrm{MW}$ transformers, considering 30 years of life expectancy.

\subsubsection{Key additional assumptions}

In the absence of specific or semi-specific data for plant building operations (excavation, track construction), for engines composition (used in mobile installations) and for waste structures management (waste modules and supports), the model is based on hypothesis gathered in a Supporting information sheet. In particular, the necessary road to access the installation is assumed to be $3 \mathrm{~km}$ long. Moreover, multi-crystalline modules are assumed to be entirely recycled at the end of the installation life, by use of a thermal/chemical treatment. The life cycle inventory corresponding to modules recycling is partly based on literature data [20] completed with additional assumptions. 
Table 3. Data collection for infrastructures in scenarios

\begin{tabular}{|c|c|c|c|c|}
\hline & Scenario 1 & Scenario 2 & Scenario 3 & Scenario 4 \\
\hline Modules & \multicolumn{4}{|c|}{$35714 \mathrm{~m}^{2}$ - value based on calculations from energy production performances } \\
\hline Area & $92888 \mathrm{~m}^{2}(*)$ & $92888 \mathrm{~m}^{2}(*)$ & $96922 \mathrm{~m}^{2}(*)$ & $418770 \mathrm{~m}^{2}(*)$ \\
\hline Supports & $\begin{array}{l}\text { Primary aluminum - } \\
\text { Mass values from } \\
\text { technical sheets from a } \\
\text { German manufacturer }\end{array}$ & $\begin{array}{l}\text { Wood, primary } \\
\text { aluminum and iron - } \\
\text { Mass values from data } \\
\text { from a multi-MWp } \\
\text { installation in France }\end{array}$ & $\begin{array}{l}\text { Galvanized steel - } \\
\text { Mass values from } \\
\text { technical sheets } \\
\text { from a Spanish } \\
\text { manufacturer }\end{array}$ & $\begin{array}{l}\text { Galvanized steel- } \\
\text { Mass values from } \\
\text { technical sheets } \\
\text { from an Italian } \\
\text { manufacturer }\end{array}$ \\
\hline Foundations & $\begin{array}{l}\text { Cast iron stakes - } \\
\text { approximation based on } \\
\text { technical sheets from an } \\
\text { Austrian manufacturer }\end{array}$ & $\begin{array}{l}\text { Concrete - Mass values } \\
\text { from data from a multi- } \\
\text { MWp installation in } \\
\text { France }\end{array}$ & $\begin{array}{l}\text { Concrete - Mass } \\
\text { values from } \\
\text { implementation } \\
\text { schemes }(*)\end{array}$ & $\begin{array}{l}\text { Concrete - Mass } \\
\text { values from } \\
\text { implementation } \\
\text { schemes }(*)\end{array}$ \\
\hline Cabling & \multicolumn{4}{|c|}{ Copper, aluminum and PVC - Mass values from implementation schemes $(*)$} \\
\hline Transformers & \multicolumn{4}{|c|}{ Reference flows data compiled from a French manufacturer } \\
\hline $\begin{array}{l}\text { Complementary } \\
\text { infrastructures }\end{array}$ & \multicolumn{4}{|c|}{$\begin{array}{l}\text { Control center building made of steel reinforced concrete + steel wire fences - Reference } \\
\text { flows data compiled from a German manufacturer for one installation }\end{array}$} \\
\hline
\end{tabular}

$\left({ }^{*}\right)$ computed from the experience of the consulting and engineering partner (Transénergie)

\section{Results}

\subsection{Scenarios comparison}

The Life Cycle Impact Assessment results are shown in Figure 2 and Table 4. Negative values represent the environmental benefits of recycling. Those environmental benefits are not taken into account in the global results since they could be applied in another production chain where recycled aluminum is used. Scenario 1, considering fixed-mounting virgin aluminum supports, shows the largest environmental impacts in terms of human health, global warming and resources, while Scenario 4 (dual-axis tracker systems) generates the largest impacts on ecosystem quality. Scenarios 2 and 3 (fixed-mounting wood-based and single-axis trackers) globally show the best environmental performances, with gaps between their potential damage impacts ranging from 1 to $3 \%$ depending on the considered category.

\subsection{Detailed environmental performances}

\subsubsection{Climate change}

Modules manufacturing represents the largest share of climate change impact for all scenarios (38 - 56\% of the total impact). Moreover, virgin aluminum supports manufacturing stands for a large proportion of the total impact of scenario 1 (36\%, if including environmental benefits due to aluminum recycling), contrarily to wood-based fixed-mounting supports (Scenario 2, $21 \%$ of the total impact) and galvanized steel mobile supports (Scenarios 3 and 4, respectively 5 and 12\%). The climate change impact due to supports is 2 to 10 times larger in scenario 1 than in scenarios 2, 3 and 4 . As a consequence, the total climate change impact is $28 \%$ larger in scenario 1 than in scenario 2, whereas the climate change impact due to modules is equal for both scenarios $\left(21.4 \mathrm{~g}\right.$. $\mathrm{CO}_{2} \mathrm{eq} / \mathrm{kWh}$, a relatively low value to be related with the assumed use of the French electricity mix for modules manufacturing in scenarios).

Depending on the considered scenario, electric equipments (inverters, transformers and engines in case of mobile structures), complementary infrastructures (road, control centers) and foundations may represent a significant share of the total impact. For example, for 
scenario 4, these elements represent up to $50 \%$ of the total climate change burden. This large share is partly due to the increase in electricity production, generating the decrease in environmental impacts of modules $\left(16.1 \mathrm{~g}\right.$. $\left.\mathrm{CO}_{2} \mathrm{eq} / \mathrm{kWh}\right)$, combined with an increase of the impacts of these balance of system (BOS) components.

Table 4. Damage impact assessment results for the four scenarios (Impact 2002+method v2.04)

\begin{tabular}{lcccc}
\hline Study case & $\begin{array}{c}\text { Human health } \\
(\mathrm{DALY} / \mathrm{kWh})\end{array}$ & $\begin{array}{c}\text { Ecosystem quality } \\
\left(\mathrm{PDF} . \mathrm{m}^{2} . \mathrm{yr} / \mathrm{kWh}\right)\end{array}$ & $\begin{array}{c}\text { Climate change } \\
\left(\mathrm{g} . \mathrm{CO}_{2} \text { eq./kWh }\right)\end{array}$ & $\begin{array}{c}\text { Resources } \\
(\mathrm{MJ} \text { primary } / \mathrm{kWh})\end{array}$ \\
Scenario 1 & $4.65 \mathrm{E}-08$ & $2.46 \mathrm{E}-02$ & 53.5 & 1.10 \\
Scenario 2 & $3.24 \mathrm{E}-08$ & $2.35 \mathrm{E}-02$ & 38.0 & 0.88 \\
Scenario 3 & $3.34 \mathrm{E}-08$ & $2.32 \mathrm{E}-02$ & 37.5 & 0.90 \\
Scenario 4 & $4.12 \mathrm{E}-08$ & $5.15 \mathrm{E}-02$ & 42.8 & 0.88 \\
\hline
\end{tabular}

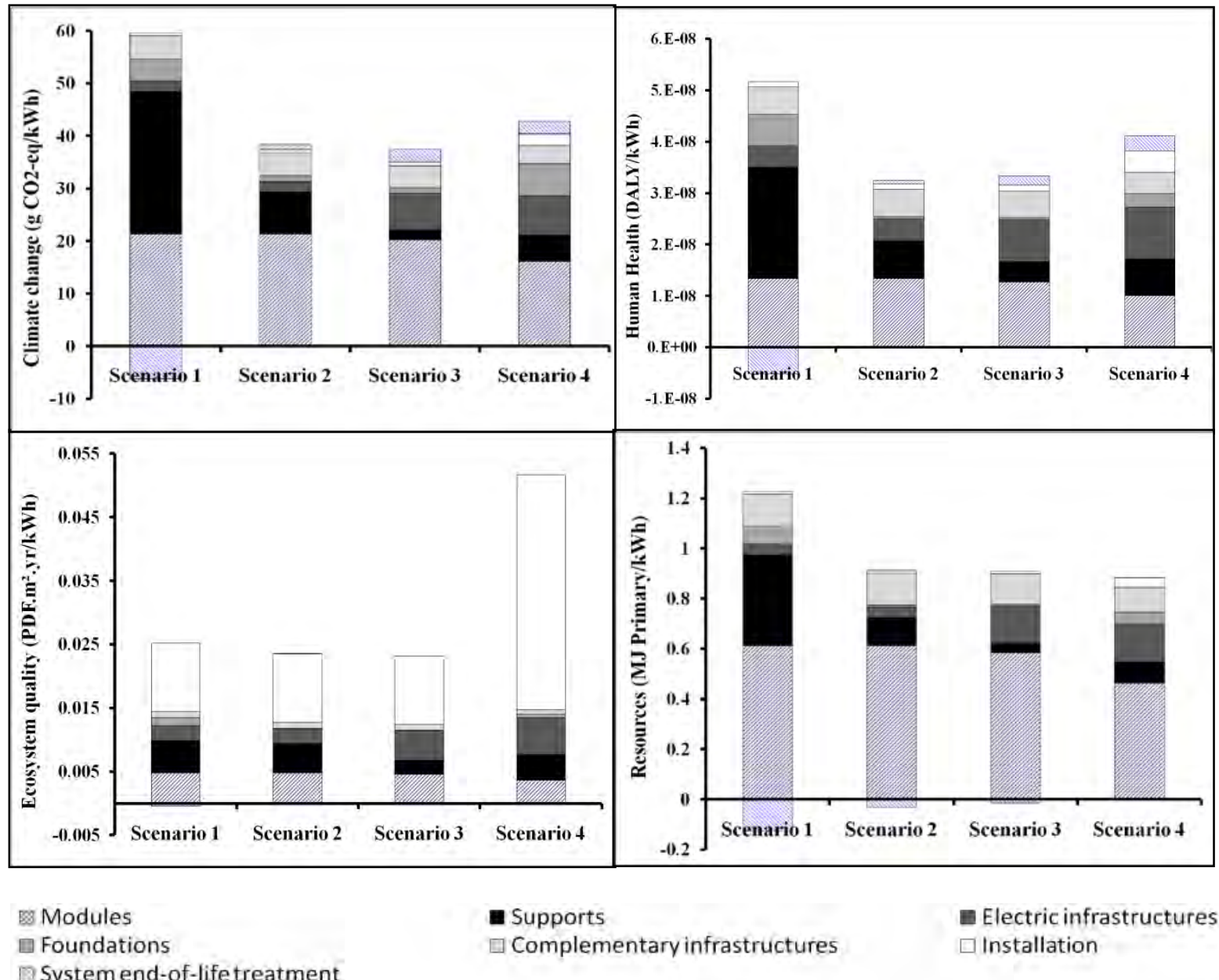

Fig. 2. Detailed environmental impacts of the 4 scenarios (considering $1700 \mathrm{kWh} / \mathrm{m}^{2} . y r$ of irradiation on an inclined plane, mc-Si modules with $14 \%$ of energy production performance and IMPACT2002+ v2.04 damage indicators)

\subsubsection{Human health}

Impacts on human health show a similar trend with the impacts on climate change, both in terms of overall impact comparison and predominant Life Cycle phases. Modules manufacturing generates the largest environmental burden for scenarios 2, 3 and 4 (from 29 to $41 \%$ of the total impact depending on the scenario), while virgin aluminum supports manufacturing represents the largest share for scenario 1 (33\% if including benefits due to 
recycling). Small particulates, $\mathrm{NO}_{\mathrm{x}}$ and $\mathrm{SO}_{2}$ air emissions related to aluminum production (due in particular to electricity requirements and mostly emitted in the aluminum country of origin) represent $22 \%$ of the total impact on human health for scenario 1 . On the other hand, the human health impact of wood (scenario 2) and galvanized steel supports (scenarios 3 and 4) is lower in absolute value and also stands for a lower share of the total impact.

\subsubsection{Resources}

Modules manufacturing contribution to the total burden on resources amounts to 53 to $70 \%$ depending on the scenario. The environmental benefit gained from the increase in electricity production in case of mobile installations, which is directly reflected in terms of modules impacts, is counterbalanced by different requirements in infrastructures (e.g. electric equipments). As a consequence, whereas scenarios 3 and 4 consider larger electricity production from 5 to $32.5 \%$ compared to scenario 2, the gap in impacts on resources between these 3 scenarios is lower than $2 \%$.

Impact on resources of virgin aluminum supports accounts for $24 \%$ of scenario 1 total impact (if including benefits from aluminum recycling). This impact is 2 to 6 times larger than impacts of wood-based and galvanized steel supports of scenarios 2, 3 and 4 .

\subsubsection{Ecosystem quality}

The impact on ecosystem quality is mainly influenced by land occupation, which represents 44 to $47 \%$ of the impact in case of scenarios 1 to 3 and up to $72 \%$ of the impact in case of scenario 4. The difference in impacts on ecosystem quality amounts to a factor 2.1-2.2 between mobile scenario 4 (dual-axis trackers) and scenarios 1 to 3, to compare with a 4.5 ratio between scenario 4 and scenarios 1-3 occupied surfaces. Indeed, power plants with dualaxes trackers require expanding the distances between each element of the PV field, because the shades induced by the moving PV planes are more important: the "power density" in terms of MWp/acre of land used is therefore much lower than for fixed-mounting systems.

\section{Discussion}

\subsection{Key environmental parameters}

Irradiation intensity received by PV installations, modules manufacturing electricity use and its corresponding fuel mix and solar radiation conversion efficiency were shown to be key environmental parameters of PV installations in several studies [9, 12]. Similarly, this study highlights the large influence of modules production, and to a lower extent of electricity production increase in mobile conditions, on the environmental performances of large-scale grid-connected ground-mounted PV installations. In addition, two other critical parameters arise: structure supports and occupied surfaces.

\subsubsection{Metal/Wood supports}

The environmental impact of supports production is predominant considering climate change, resources consumption and impacts on human health, and is responsible for the environmental gap between scenarios in several cases (e.g. between Scenarios 1 and 2). The impact of supports is firstly related with their weight: as observed by Mason et al. [15], decreasing the quantity of metal supports in large-scale installations results in significant environmental improvements. However, materials nature appears as an even more critical environmental parameter. For example, the galvanized steel supports mass is $8 \%$ larger in scenario 4 than the primary aluminum supports mass in scenario 1 (considering mass per produced $\mathrm{kWh}$ ), whereas the corresponding impact on e.g. climate change is $81 \%$ larger for supports of 
scenario 1. Moreover, a sensitivity analysis has been conducted on aluminum supports, by considering secondary material (from old scrap) instead of virgin material. The use of secondary material generates significant decreases in environmental impacts of scenario 1: $42 \%$ for climate change, $39 \%$ for human health and $25 \%$ for resources, in compliance with the predominance of supports composition on the impacts of a large-scale PV installation.

\subsubsection{Occupied surface}

The occupied surface mainly determines the impact of large-scale PV installations on ecosystem quality. Consequently, land consuming alternatives such as mobile installations with dual-axis trackers will show relatively large impacts on ecosystem quality compared to fixed-mounting solutions, if considering the same modules technology.

\subsection{Comparing large-scale grid-connected ground-mounted PV installations}

The ranking of alternatives and their associated key parameters may differ from one environmental indicator to another, as observed when putting in perspective large-scale PV installations impacts on climate change and ecosystem quality. This study therefore enhances the need for a multi-criteria impact assessment method when comparing large-scale gridconnected ground-mounted PV installations. In addition, the results underline the multiplicity of parameters which may affect large-scale PV installations environmental performances. The environmental impacts of large-scale PV installations are the result of the interplay between a number of distinct parameters (e.g. energy production, supports mass and nature, electric equipments, etc.), whose related influence may counterbalance each other.

\section{Conclusions, recommendations and perspectives}

The impact assessment of large-scale ground mounted PV installations therefore gives a detailed picture of their related environmental performances. Key installations design parameters arise in an environmental perspective: supports mass and composition, power density (in MWp/acre of land) and energy production performances, in addition to key parameters related to modules manufacturing (in particular electricity consumption and electricity production mix).

The environmental performances of large-scale PV installations are not in linear correlation with a unique quantified plant parameter. In that sense, for example, increasing the electricity production thanks to mobile technologies does not necessarily bring environmental benefits if combined with an increase in requirements in materials. A multi-criteria perspective - with respect to environmental indicators and installations key design parameters - should be undertaken with a view to optimizing PV large-scale installations environmental performances in a near future.

\section{Acknowledgements}

ADEME is co-financing this project which brings together different French specialists from the PV industry and LCA fields.

\section{References}

[1] IEA. Trends in photovoltaic applications: Survey report of selected IEA countries between 1992 and 2006, Report IEA-PVPS T1-16:2007

[2] Syndicat des énergies renouvelables (SER), SOLER. Etat des lieux du parc photovoltaïque français au 30 juin 2010. 2010. 
[3] European Commission, Directorate-General for Research. External Costs. Research results on socio-environmental damages due to electricity and transport. Office for Official Publications of the European Communities, Luxembourg. 2003.

[4] Australian Coal Industry Association, ACARP. Coal in a sustainable society. 2004.

[5] V.M. Fthenakis, E.A. Alsema, M.J. de Wild-Scholten. Life Cycle Assessment of Photovoltaics: perceptions, needs and challenges. $31^{\text {st }}$ IEEE Photovoltaic Specialists Conference. 2005.

[6] N. Jungbluth, M. Tuchschmid, R. Dones. Photovoltaics: ecoinvent report N 6-XII. Swiss Center for Life Cycle Inventories, Dübendorf, CH. 2007.

[7] E.A. Alsema, M.J. de Wild-Scholten, V.M. Fthenakis. Environmental impacts of PV electricity generation - A critical comparison of energy supply options. 2006.

[8] IEA. Analysis of PV system's values beyond energy - by country and stakeholder. Report IEA-PVPS 10-02:2008

[9] S. Pacca, D. Sivaraman, G. A. Keolian. Parameters affecting the life cycle performance of PV technologies and systems, Energy Policy, 2007, vol. 35, nº 6, pp. 3316-3326

[10]R. Kannan, K.C. Leong, R. Osman, H.K. Ho, C.P. Tso. Life cycle assessment study of solar PV systems: An example of a $2.7 \mathrm{~kW}(\mathrm{p})$ distributed solar PV system in Singapore, Solar Energy, 2006, vol. 80, n55, pp. 555-563

[11] I. Blanc, D. Beloin-Saint-Pierre, J. Payet, P. Jacquin, N. Adra, D. Mayer. Espace-PV: key sensitive parameters for environmental impacts of grid-connected PV systems with LCA. 23rd European Photovoltaic Energy Conference. 2008.

[12]D. Beloin-Saint-Pierre, I. Blanc, J. Payet, P. Jacquin, N. Adra, D. Mayer. Environmental impact of PV systems: effects of energy sources used in production of solar panels. 24th European Photovoltaic Energy Conference. 2009.

[13]K. Komoto, H. Uchida, M. Ito, K. Kurokawa, A.Inaba. Estimation of Energy Payback Time and $\mathrm{CO}_{2}$ Emission of Various Kinds of PV Systems, 23rd European Photovoltaic Energy Conference. 2008.

[14] J.M. Mason, V.M. Fthenakis, T. Hansen and H.C. Kim. Energy Pay-Back and Life Cycle $\mathrm{CO}_{2}$ Emissions of the BOS in an Optimized 3.5 MW PV Installation. 2006.

[15] International Standard Organization. ISO 14040. Environmental management - Life Cycle Assessment - principles and framework. 2006.

[16] International Standard Organization. ISO 14044. Environmental management - Life Cycle Assessment - requirements and guidelines. 2006.

[17] Institute for Environment and Sustainability. Joint Research Centre. European Commission. International Reference Life Cycle Data System handbook. 2010

[18]O. Jolliet, M. Margni, R. Charles, S. Humbert, J. Payet, G. Rebitzer, R. Rosenbaum. Impact 2002+: A new life cycle impact assessment methodology, International Journal of Life Cycle Assessment. 2003. Volume: 8, Issue: 6, Pages: 324-330.

[19] Swiss Center for Life Cycle Inventories. The life cycle inventory data version 2.0. http://www.ecoinvent.ch. 2008.

[20]A. Müller, K. Wambach, E. Alsema. Life Cycle Analysis of solar module recycling process. 20th European Photovoltaic Solar Energy Conference. 2005. 